\title{
Marketing and Financial Competencies of Malaysian Malays Micro-Entrepreneurs
}

\author{
Abu Bakar Sedek Abdul Jamak, Mohd Yussoff Ibrahim, Rohani Salleh, and Azelin Mohamed Noor
}

\begin{abstract}
This paper focuses on the micro-entrepreneurs of Malaysian Malays who are involved in very small-scale business activities. The study seeks to identify the impact of marketing and financial competencies on their success and what needs to be rectified. This quantitative study is conducted on 173 Malay micro-entrepreneurs (MEs) and 58 Malay failed micro-entrepreneurs (FMEs) involved in all range of businesses throughout the state of Perak, Malaysia. The main aims are to present the pathway of successful Malay entrepreneurs the factors that could motivate them to start a micro business and the skills required to run a business and keep growing. This paper also identifies the gaps between the FMEs and existing MEs and the problems faced among FMEs. The results reveal that the MEs had strong motivations, better marketing approaches and better financial competence as compared to FMEs. Furthermore, the FMEs failed in business ventures mainly due to lack of sales and marketing skills, poor competitive abilities to keep up with rivals and poor financial literacy.
\end{abstract}

Index Terms-Entrepreneurship, marketing, financial literacy, Malays, micro-entrepreneurship.

\section{INTRODUCTION}

Malaysia's population is made up of many ethnic groups. The three major ethnic groups are Malay, Chinese and Indian. The population of East Malaysia which constitutes Sabah and Sarawak, is more diverse as compared to the population in Peninsular Malaysia. Within Sabah itself, there are about 31 different indigenous groups which include the larger communities like Kadazan and Bajau. In Sarawak, there are about 26 indigenous groups including the Iban, Bidayuh and Penan [1]. The Malays together with the indigenous groups in Malaysia are recognized by Malaysia's constitution as the "sons of the soil" or the Bumiputera [2]. The Bumiputera enjoys numerous rights and privileges under the constitution. These rights and privileges include employment in the public service, entitlement to scholarships and education, and reservation of permits or licenses for trade and businesses [2].

Although participation of the Malays in the entrepreneurial sector had improved following independence, the stark reality of their under-representation in this rapidly growing sector remained the same. For example in 1954, out of 76,673 business units registered in the Federation of Malaya, only 7878 units or about $10 \%$ were owned by the Malays with the Chinese and the Indians owning 58,005 units (73\%) and $12,696(17 \%)$ respectively [3]. This situation improved only slightly in 1961 . Out of 84,930 sole proprietorship registered in the country, only $11648(12 \%)$ were owned and managed

Manuscript received October 1, 2013; revised December 3, 2013.

Abu Bakar Sedek Abdul Jamak is with Universiti Teknologi PETRONAS, CO 31750 Malaysia (e-mail: abubakar_sedek@petronas.com.my). by Malays. The overall ratio of Malay firms to non-Malay was 1:7 [4].

The racial riot of 13 May 1969 served as an eye opener for many regarding the fragility of Malaysia's pluralistic society [5]. Recognizing the severity of the problems and the urgent need to address them, the government through the National Operations Council (NOC) introduced the far reaching reforms of the New Economic Policy (NEP) [6], [7]. Guided by the principles of Rukun Negara, the NEP was formulated with the overriding objective of achieving national unity through the two-pronged strategy of:

1) Eradicating poverty by raising income levels and increasing employment opportunities for all Malaysians, irrespective of races;

2) Accelerating the process of restructuring Malaysian society to correct economic imbalances, so as to reduce and eventually eliminate the identification of race with economic function [8].

It is important to explain the why the government is pushing towards more successful Malay society in this new era of country's economic development. According to [9], the majority $(60 \%)$ of companies in Malaysia are contributed by micro enterprises as compared to small (28\%), medium sized (9\%) and large sized enterprises (3\%). The importance of micro enterprise in the development of all sectors in Malaysia suggests that an understanding of the success factors is crucial to the stability and health of Malaysia's economic advancement towards vision 2020 .

According to the National SME Development Council of Malaysia, Small and Medium Enterprises (SME) are categorized according to 1) number of employees; or 2) annual sales turnover. The National SME development Council had, on 9 June 2005, approved the common definitions of SMEs across economic sectors, for adoption by all Government Ministries and Agencies involved in SME development, as well as financial institutions. A micro enterprise in primary agriculture is an enterprise with full-time employees of less than 5 or with annual sales turnover of less than RM 250,000 (about USD 80,600). A micro enterprise in manufacturing (including agro-based) and manufacturing related services (MRS) is an enterprise with full-time employees of less than 5 or with annual sales turnover of less than RM250,000. A micro enterprise in services is an enterprise with full-time employees of less than 5 or with annual sales turnover of less than RM250,000.

Past research has found that internal factors such as marketing orientation, entrepreneurial personality as well as attracting and retaining customers are key determinants of small business success [10] although, it is recognized that factors such as the age of the firm will affect the importance of each. Amongst the problems encountered by micro and small entrepreneurs include the difficulty in finding new 
customers (sales) and to retain them because the customers lacked the trust and confidence in Malay or Bumiputera businessmen [11]. Other customer related problems involve collecting payments from the customers, lacking customer focus, and having too narrow customer base. Poor sales and marketing has always been recognized as a problem faced by micro and small businesses [12]. No matter how small the operation of the business is, promotion is an important tool to be competitive in the market [13]. Harvard Business School professor Theodore Levitt once said: "The purpose of every business is to create and keep a customer."

The need for financial literacy has become significant with the deregulation of financial markets and easier access to credit as financial institutions compete strongly with each other for market share, the rapid growth in development and marketing of financial products, and Government's encouragement for people to take responsibility for their business incomes. Furthermore, the high number of people with low levels of financial literacy presents a serious problem for both the economic well-being of nations and the personal well-being of such businessmen [14], [15].

It was pointed out that competency in numeracy and literacy must be the platform for improvements and growth in indigenous self-employment [16]. Approximately 80 percent of business failures are because of inferior management on the internal control especially on the financial capital management [17]. Consequently, financial literacy has attracted increasing attention in both the developed and developing world due to its role in management decision.

\section{ISSUES AND PROBLEMS}

In Malaysia, TEKUN (Tabung Ekonomi Kumpulan Usaha Niaga / Entrepreneurship Group Economic Fund), a Government-linked agency under the Ministry of Agriculture and Agro-based industry, was set up to provide micro loan facilities of not more than RM 50,000 and other supported services to facilitate entrepreneurial development for micro business owners especially Bumiputra Malays. Since launched in 1988, 139,105 entrepreneurs had benefited in getting loan facilities from TEKUN. Furthermore, in the year 2010, RM162 million loan facilities were available in order to produce 17,000 entrepreneurs [18]. Some of the initiatives and support provided by TEKUN are training and mentoring programmes, business networking, in identifying business opportunities and selecting and monitoring relevant businesses for entrepreneurial growth development.

TEKUN faces colossal problems with debt collection to the extent that they have to dispatch officers to business premise instead of having them come over to the TEKUN offices to pay their dues. A massive nationwide collection campaign was also carried out in 2012. According to Datuk Abdul Rahim Hassan, managing director and CEO of TEKUN Nasional, about 30\% from 170,000 micro borrowers of TEKUN in Malaysia have failed in the repayment of their loans since this agency was formed in 1989 [18]. It was noted that most of them declined to service their loans due to the problems encountered in their business performance and also their businesses were not viable apart from making losses. Why are these micro business owners slow and weak in the repayment of their loans? Could their behavior, attitude, poor business performance or other financial factors such as poor collection and poor bottom line analysis be some of the attributing causes?

Datuk Mohd Johari Baharom, Deputy Minister of Agriculture and Agro-based industry in the Agro-based Industry Entrepreneurs Seminar 2010 stated that, based on the records provided, the borrowers lacking basic business skills are more likely exposed to risks for failing in business venture [19]. He added that the Ministry was forced to tighten up selections because past record shows that, there were too many borrowers who did not utilize their loans in proper ways resulting in the failure of their business. Many studies have been done on SMEs indicating that growth and key success factors contribute to venture growth, yet only $10 \%$ of these start-ups survived beyond the 10 year mark. A total of 79,310 businesses were discontinued in Malaysia during the year 2002 as most were unable to cope with the transition from an entrepreneurial style of management to an organized, professionally managed workforce. And as a result, they were unable to capitalize on new market opportunities [20]. Studies also revealed that more than $90 \%$ of new start-up businesses fail within 5 years of operation. As an effort to rectify the problem, the government has directed more government-linked agencies to get involved in assisting to develop new Malay micro entrepreneurs among fresh graduates.

The ministry of agriculture and agro-based industry are trying to guide and coach some 2,000 micro entrepreneurs to upgrade their status as entrepreneurs of small and medium sized industry. Among other things discussed in the dialogue with the micro entrepreneurs was to find ways on how to push their business income of currently below RM250,000. So far, the ministry has discovered that from 2,000 micro entrepreneurs, only about 200 entrepreneurs achieved a RM250.

000 yearly sales and can be promoted as SMI entrepreneurs.

Since the introduction of National Economic Policy (NEP), the government had drawn all possible action plan and implementation strategies to increase the number of successful Malay entrepreneurs. Several funds particularly in assisting the Malays to start or grow their business such as New Entrepreneurs Fund, Small Industry Fund and Business Effort Fund had been introduced [21]; however, the corporate ownership of Malays in Bursa Malaysia is merely $21.9 \%$ in 2012. Based on the above stated problems, the present study was motivated to help the Malay micro and small enterprises' weak position in the Malaysian economic sector and examine ways to keep their businesses growing and to find ways for the Malay micro and small enterprises to not be left behind in the progress towards vision 2020 .

\section{RESEARCH OBJECTIVES}

The following are important questions as the government is committed to developing Malay MEs and be more competitive in the business world. Why do some micro-entrepreneurs still lag in entrepreneurship and what needs to be rectified among them? Furthermore, what are the skills that micro-entrepreneurs need to develop to become more enterprising so that their livelihood will no longer 
depend on the government?

Among the key factors raised included the significant difference between existing MEs and FMES in terms of their marketing skills and financial literacy.

Not much has been studied on entrepreneurial abilities of micro-entrepreneurs of Bumiputra Malays in Malaysia. This study, therefore, aims to evaluate the entrepreneurial skills of the Malays who have ventured in micro enterprise businesses. This study focuses on two (2) main aspects: financial literacy and marketing skills. Specifically, this research has the following objectives:

- To identify the gaps between FMEs and existing MEs among Malaysian Malays in terms of marketing strategies and financial literacy.

- To identify factors leading to the failures among FMES.

- To investigate problems encountered by FMEs that led to their business failure.

\section{RESEARCH METHODOLOGY}

A questionnaire was used to collect data for the study. The demographic details of the respondents, three aspects were also studied, namely personal characteristics, marketing skills and financial literacy of both existing MEs and FMEs were solicited. The items were developed from literature review and reference from TEKUN officers who were involved with repayment collections. The first section comprised of questions related to the respondents' business profile, followed by the second section on personal background, then it continued with marketing objectives and strategies and the last section focused on their financial literacy approach.

With the assistance from TEKUN, 221 MEs and 72 FMEs were identified as potential respondents for the study. MEs are defined as those whose businesses with less than 5 full-time employees, while those who failed to continue loan repayment (ie. refuse or could not afford) and stopped doing business are considered FMEs.

The data of the study was collected over two months. The authors, accompanied by TEKUN officers visited the micro business owners at their business premises throughout the state of Perak. The respondents were involved in trading services (retailers and other types of middlemen), food and beverage services (like food stalls and restaurants), tourism, automotive repair work, building contracting works, manufacturing and agricultural services. In total, 173 MEs and 58 FMEs participated in the study.

\section{RESPONDENTS' BACKGROUND}

The background of both MEs and FMEs are categorized into three: education background, business experience and upbringing that influences on entrepreneurial choices. As shown in Table I, $93.1 \%$ of the FME respondents and $84.4 \%$ of the ME respondents have secondary school education and below. Of the FMEs, most (77.6\%) failed their businesses within six years. Almost all $(99 \%)$ of the MEs have been in business for less than 10 years. More than half of the MEs $(51.5 \%)$ had their parents and upbringing that influence their entrepreneurial choices as compared to FMEs of only $24.1 \%$.
This suggests that parents and upbringing influence is one important criterion in impacting the success in MEs.

TABLE I: BACKGROUND

\begin{tabular}{|l|l|l|l|l|l|}
\hline \multirow{2}{*}{ Items } & Variables & MEs & $\%$ & FMEs & $\%$ \\
\hline \multirow{4}{*}{$\begin{array}{l}\text { Highest } \\
\text { level of } \\
\text { education }\end{array}$} & No formal education & 1 & 0.6 & 3 & 5.2 \\
\cline { 2 - 6 } & Primary level & 22 & 12.7 & 8 & 13.8 \\
\cline { 2 - 6 } & Secondary level & 123 & 71.1 & 43 & 74.1 \\
\cline { 2 - 6 } & Tertiary & 16 & 9.2 & 3 & 5.2 \\
\cline { 2 - 6 } & Upper tertiary & 11 & 6.4 & 1 & 1.7 \\
\cline { 2 - 6 } & Total & 173 & 100 & 58 & 100 \\
\hline \multirow{4}{*}{$\begin{array}{l}\text { Business } \\
\text { existence }\end{array}$} & Less than 1 year & 31 & 17.9 & 5 & 8.6 \\
\cline { 2 - 6 } & $1-3$ years & 70 & 40.5 & 28 & 48.3 \\
\cline { 2 - 6 } & $4-6$ years & 60 & 34.7 & 12 & 20.7 \\
\cline { 2 - 6 } & $7-10$ years & 10 & 5.8 & 6 & 10.3 \\
\cline { 2 - 6 } & 10 years and above & 2 & 1.2 & 7 & 12.1 \\
\cline { 2 - 6 } & Total & 173 & 100 & 58 & 100 \\
\hline \multirow{3}{*}{$\begin{array}{l}\text { Parents and } \\
\text { upbringing }\end{array}$} & Yes & 89 & 51.5 & 14 & 24.1 \\
\cline { 2 - 6 } & May be & 39 & 22.5 & 7 & 12.1 \\
\cline { 2 - 6 } & No & 45 & 26.0 & 37 & 63.8 \\
\cline { 2 - 6 } & Total & 100 & 58 & 100 \\
\hline
\end{tabular}

\section{FINDINGS}

\section{A. The Marketing Objectives and Strategy of} Micro-Entrepreneurs (MEs)

TABLE II: MARKETING OBJECTIVES

\begin{tabular}{|c|c|c|c|c|c|}
\hline Items & Variables & MEs & $\%$ & FMEs & $\%$ \\
\hline \multirow{7}{*}{$\begin{array}{l}\text { Main } \\
\text { objective } \\
\text { for the } \\
\text { past } 5 \\
\text { years }\end{array}$} & For survival & 18 & 10.4 & 19 & 32.8 \\
\hline & To prevent loss & 18 & 10.4 & 2 & 3.4 \\
\hline & To improve sales & 72 & 41.7 & 20 & 34.5 \\
\hline & $\begin{array}{l}\text { To improve current } \\
\text { market share }\end{array}$ & 2 & 1.2 & 1 & 1.7 \\
\hline & $\begin{array}{l}\text { To expand into new } \\
\text { market and } \\
\text { opportunity }\end{array}$ & 62 & 35.8 & 13 & 22.4 \\
\hline & Others & 2 & 1.2 & 3 & 5.2 \\
\hline & Total & 173 & 100 & 58 & 100 \\
\hline \multirow{7}{*}{$\begin{array}{l}\text { Main } \\
\text { objective } \\
\text { for the } \\
\text { next } 5 \\
\text { years }\end{array}$} & For survival & 5 & 2.9 & - & - \\
\hline & To prevent loss & 13 & 7.5 & - & - \\
\hline & To improve sales & 46 & 26.6 & - & - \\
\hline & $\begin{array}{l}\text { To improve current } \\
\text { market share }\end{array}$ & 8 & 4.6 & - & - \\
\hline & $\begin{array}{l}\text { To expand into new } \\
\text { market and } \\
\text { opportunity }\end{array}$ & 98 & 56.6 & - & - \\
\hline & Others & 3 & 1.7 & - & - \\
\hline & Total & 173 & 100 & - & - \\
\hline
\end{tabular}

As shown in Table II, over the past five years, the MEs indicated "to improve sales" (41.7\%) followed with "to expand into new market and opportunity" (35.8\%) as their main objectives. For the next five years, there is a shift in their objectives as "to expand into new markets and opportunity" (56.6\%) has been indicated as their main objective. "To improve sales" has decreased in priority from $41.7 \%$ to $26.6 \%$.

For the FMEs, it was interesting to discover that although, "to improve sales" (34.5\%) has also been their main marketing objective, "for survival" $(32.8 \%)$ has been indicated as their second highest objective. This suggests that the FMEs are less motivated when they set their objective in 
doing business.

TABLE III: MARKETING STRATEGY

\begin{tabular}{|l|l|l|l|l|l|}
\hline \multirow{2}{*}{ Items } & \multicolumn{2}{|l|}{ MEs } & \multicolumn{2}{l|}{ FMEs } & $\begin{array}{l}\text { Mann-Whitney U } \\
\text { Test }\end{array}$ \\
\cline { 2 - 6 } & Mean & SD & Mean & SD & Sig. \\
\hline $\begin{array}{l}\text { Always } \\
\text { observing } \\
\text { rivals' } \\
\text { movement and } \\
\text { tactics }\end{array}$ & 1.94 & 0.79 & 2.24 & 0.89 & $0.02^{* *}$ \\
\hline $\begin{array}{l}\text { Keen to learn } \\
\text { more } \\
\text { successful in } \\
\text { sales and } \\
\text { marketing }\end{array}$ & 1.48 & 0.57 & 1.91 & 0.63 & $0.00^{* *}$ \\
\hline $\begin{array}{l}\text { Take approach } \\
\text { towards } \\
\text { quality } \\
\text { compared to } \\
\text { rivals }\end{array}$ & 2.26 & 0.96 & 2.54 & 1.02 & $0.04^{* *}$ \\
\hline $\begin{array}{l}\text { Take steps to } \\
\text { boost sales } \\
\text { from time to } \\
\text { time }\end{array}$ & 2.13 & 1.04 & 2.40 & 0.90 & $0.03^{* *}$ \\
\hline
\end{tabular}

Note:** the significance level is .05 .

As for the marketing strategy, the results of the Mann-Whitney U-Test presented in Table III indicate significant difference between FMEs and MEs with regards to all four aspects. Specifically, our findings reveal that the MEs have significantly higher inclination to "observe competitors" movement and tactic" (Sig. 0.020, $p<0.05$ ), "learn to be more successful in sales and marketing" (Sig. $0.000, p<0.05)$, "approach towards quality compared to rivals" (Sig. 0.042, $p<0.05$ ) and "steps to boost sales" (Sig. $0.028, p<0.05)$ compared to the FMEs. The findings suggest that compared to MEs, the attitudes of FMEs towards marketing are rather passive and are less effective in applying marketing innovations and less motivated in enhancing their businesses, and this translates into weak overall performances and business failure.

\section{B. Problems Encountered the Failed Micro-Entrepreneurs (FMEs)}

TABLE IV: FACTORS FOR BUSINESS FAILURES

\begin{tabular}{|l|c|c|}
\hline Factors & No. of FMEs & $\%$ \\
\hline $\begin{array}{l}\text { Lack of management, sales and marketing } \\
\text { skills }\end{array}$ & 7 & 12.1 \\
\hline $\begin{array}{l}\text { Lack of knowledge in finance and book } \\
\text { keeping }\end{array}$ & 3 & 5.2 \\
\hline High rivals intensity & 16 & 27.6 \\
\hline Less customers /small market & 13 & 22.4 \\
\hline Lack of motivation & 1 & 1.7 \\
\hline Give up because of other choice & 3 & 5.2 \\
\hline Others & 12 & 20.7 \\
\hline Missing & 3 & 5.2 \\
\hline & $\mathbf{5 8}$ & $\mathbf{1 0 0}$ \\
\hline
\end{tabular}

As shown in Table IV, during the start-up phase, FMEs faced three main problems: high rivalry $(27.6 \%)$, lack of customers $(22.4 \%)$ and lack of management, sales and marketing skills (17.3\%) which led them to business failure. These are common problems among micro and small businesses. Some stated they were simply not prepared to face competitions and poor in applying marketing strategy as rivalry s became more intensified. Some of them said that they had tried tactically to keep up with rivals but were still unable to sustain in the market.

Under "others" (20.7\%), some FMEs stated that they were hit by spiritual disturbances (black magic), that they could not carry out their business and lastly gave up. This evidently occurred where the business premises were located in town areas and the intensity of competition among the traders was high. Apart from that, others said the other reasons were poor control of cash flow, lack of support from local government and not profitable businesses.

Under "others" (20.7\%), some FMEs stated that they were hit by spiritual disturbances (black magic), that they could not carry out their business and lastly gave up. This is evidently occurred whereby the business places are located in town areas and the intensity of competition among the traders is high because of survival. Apart from that others said the reasons are that poor control of cash flow, lack of support from local government and not profitable business.

\section{Financial and Accounting Literacy}

Respondents were investigated on their level of financial literacy to ascertain whether these factors influenced the success of their enterprise. Four aspects were covered; capital management, sales and profit management, receivables and payables management and financial reporting.

On the capital management, respondents from the two groups were assessed on the level of knowledge they have regarding the amount of capital invested on the business using three points Likert-scale with ' 1 ' indicating 'know the total amount' and ' 3 ' indicating 'not sure' and ' 2 ' indicating 'having rough estimate'.

On the sales and profit management, the respondents were tested on how they monitor the sales and profit of the business. To monitor the sales and profit, business owner must keep track of the amount regularly. A five point Likert-scale was used to get the respondent's knowledge of the monthly sales and profit, with (1) 'Knows the amount' to (5) 'Not knowing what it means'.

On the Receivables and Payables management three aspects were assessed; collection/disbursement efficiency, ability to pay debt, and record keeping. On the collection/disbursement efficiency, respondents were assessed on 'number of default debtors' and the 'number of creditors demanding payment' using a three point Likert-scale from (1) 'increasing' to (3) 'Reducing'. In both situations, 'increasing' would indicate inefficient management (poor collection or disbursement) while 'reducing' reflect efficient management.

Successful or efficient entrepreneur would settle their debt before or on the due date. Inefficient entrepreneur (for particular reason) would delay the payment longest possible. Using a three point Likert-scale from (1) 'before demanded' to (3) 'after repeated demand' respondents were assessed on their debt repayment practices.

Good management of receivables and payables requires entrepreneur to keep the bills and invoices intact. There should not be any invoices or bills missing. Respondents were asked to response a five points Likert-scale form (1) 'keeping all' to (5) 'Not keeping any'.

Finally, on the financial reporting, entrepreneurs were 
assessed on whether they do prepare financial statement or not. Entrepreneurs preparing financial statement regularly would be able to monitor their business performance or financial position effectively than those not. A dichotomous scale of (1) for 'prepare' and (2) for 'do not prepare' was used.

Using the Mann-Whitney U Test, the responses from the MEs and FMEs; are compared to assess whether there are differences between the two groups. Table $\mathrm{V}$ shows the results of the tests.

TABLE V: FINANCIAL LITERACY

\begin{tabular}{|c|c|c|c|}
\hline Item & Financial aspects & Financial Literacy & Sig. \\
\hline 1 & Capital management & $\begin{array}{l}\text { Know the capital amount } \\
\text { invested }\end{array}$ & 0.40 \\
\hline 2 & \multirow{2}{*}{$\begin{array}{l}\text { Sales and profit } \\
\text { management }\end{array}$} & Know the monthly profit & 0.16 \\
\hline 3 & & Know the monthly sales & $0.00 * *$ \\
\hline 4 & \multirow{4}{*}{$\begin{array}{l}\text { Receivables and } \\
\text { payables } \\
\text { management }\end{array}$} & Number of default debtors & 0.58 \\
\hline 5 & & $\begin{array}{l}\text { Number of creditors } \\
\text { demand payment }\end{array}$ & 0.40 \\
\hline 6 & & Debt Payment practice & $0.00 * *$ \\
\hline 7 & & $\begin{array}{l}\text { Keeping record of } \\
\text { transaction }\end{array}$ & $0.00^{* *}$ \\
\hline 8 & Financial reporting & Prepare financial statements & $0.00 * *$ \\
\hline
\end{tabular}

From the result, it is revealed and evident that four of the elements of financial literacy: knowing monthly sales, debt payment practices, record keeping, and financial reporting, indicate significant differences in the level of literacy between MEs and FMEs.

\section{RECOMMENDATION AND CONCLUSION}

The objectives of this study were to compare the MEs and FMEs in Perak, and to identify their attitudes towards marketing strategies and motivational issues. Based on the findings, it can be suggested that lack of proper training and lack in objectivity setting may have contributed towards business failure of the FMEs.

The FMEs should be prepared on ways to handle competition by employing various marketing strategies. Survival is an important element in micro enterprise environment. Rivals will pursue through various means of attacking their counterparts to remain in the market. Rivals use various strategies such as black magic which is very commonly reported. Business rivals also consider using other tactics such as pricing factors, promotional materials, word-of- mouth, and other kinds of fascinations to please and keep their customers from being lured by other competitors.

Findings from this survey suggest some practical implications. First, the significant differentiating factors between FMEs and MEs are: possessing a clear set of marketing objectives in applying marketing strategy. To become entrepreneur, changing the mindset of MEs from being mere cottage-based, backyard industries or small family-based operations, is crucial but first they must have high determination to achieve set goals.

Second, for the MEs to become better performers, they need to be aware of the central importance of marketing skills. To achieve this, training must be used by the authorities as an agent of change in assisting the MEs to create a more marketing-oriented culture such as how to attract the customers, keep them and grow with them. Marketing is defined as a 'social and managerial process by which individuals and groups obtain what they need and want through creating, offering and exchanging products of value with others' [22]. Reference [22] believed that stronger marketing skills could potentially launch a new era of high economic growth and rising living standards.

Third, to survive in changing competitive world, the MEs should always stay alert against their rivals and be innovative in applying competitive strategy. Applications of uniquely differentiated products and strong marketing mix strategy will help them distinctively to prolong their stay in the market place and hence advancing towards next level of the enterprise. Hence, enterprises should have initiative to improve their sales and profit through innovative marketing and entrepreneurial mindset.

Fourth, changing the mindset of MEs should be supported by strong key motivation factors. Hence, they should be equipped and push further in the ability to make preparation of both short term and long term planning with strategic thinking appear to be essential ingredients to becoming a better performing entrepreneur. Once MEs are trained and well-motivated, they would become better achievers with increased chances of success. To reach the next level of enterprise, MEs should be able to organize and conduct proper system and operations to ensure running smooth of the organization.

Fifth, the financial literacy of the MEs needs to be enhanced through trainings and awareness program. They need to be exposed to the basic and fundamental concepts of financial management like planning, controlling, record keeping and performance monitoring. They should be guided towards good business practices in relation to financial management like maintaining good relationship with customers and suppliers with respect to cash collection and payment, keeping records complete and close monitoring of sales and profit by producing financial reports regularly, and these will strengthened the foundation as their business grow.

Sixth, the local government needs to be more innovative in its dealing with micro enterprises such as strategy in streamlining of government processes and the use of supportive programs were desired. The local government should set up cooperatives or micro-enterprise clubs or associations are desired so that they are able to get support and pushing each other for providing motivation and also networking formation. This is a place whereby all micro business owners can gather, exchange ideas, seeking opportunities, get some motivational talks, solving problems and most importantly networking among them. Network building is an important strategy where the government could help to bring more closely together all micro business owners.

Lastly, it is concluded that there is a need to conduct more extensive research on micro-entrepreneurs to broaden the scope of the present findings. Given continually evolving demographics and technological advancements, future studies could focus on identification of new problems inherent rural Malay communities. More research should also be undertaken to explore new dimensions in managerial practice, socio-economic and motivational elements that 
could lead to the development of new theory that will boost the MEs' chances of success in Malaysia.

\section{ACKNOWLEDGMENT}

The researchers and authors would like to thank the management of Universiti Teknologi PETRONAS, Tronoh, Perak for funding and supporting this research. Also, a warm thanks to all respondents for making this research possible.

\section{REFERENCES}

[1] A. Radhakrishnan, Countries of the World: Malaysia, Malaysia: Times Edition, 2003.

[2] Petaling Jaya, Federal Constitution, Malaysia: International Law Book Services, 2008.

[3] J. H. Goh, "Some aspects of Chinese business world in Malaya," Ekonomi, vol. 3, no. 1, pp. 84-95, 1962.

[4] A. Ungku, "Facts and fallacies about Malay economy-in retrospect with new expansion," Journal of Business Research, vol. 12, pp. $159-168,1962$.

[5] M. Mahathir, The Malay Dilemma, Singapore: Marshall Cavendish Editions, 1970.

[6] Crouch, Government and Society in Malaysia. New South Wales, Australia: Allen \& Unwin, 1996.

[7] P. Monash, Malay Supremacy, Auckland, New Zealand: Maygen Press, 2003.

[8] Malaysia, Mid-term Review of the Second Malaysia Plan, The Economic Planning Unit, Prime Minister's Department, 1973.

[9] National SME Development Council of Malaysia Small and Medium Industries Development Corporation (SMIDEC). (2004). [Online]. Available: http://www.smidec.gov.my/

[10] I. Chaston, "Critical event and process gap in the Danish technological institute structured networking model," International Small Business Journal, vol. 14, no. 3, pp. 35-47, 1996.

[11] Firdaus et al., "Developing a framework of success of Bumiputera entrepreneurs," Journal of Enterprising Communities: People and Places in the Global Economy, vol. 13, no. 1, pp. 8-24, 2009.

[12] H. Salleh, "Peasants, proletarianiaism and the state: Felda settlers in Pahang," in Fragmented vision: Culture and politics in contemporary Malaysia, J. S. Kahn and F. L. K. Wah, Eds. 1992, pp. 107-132.

[13] L. Ngaosi and G. Navarro, "The characteristics of selected micro entrepreneurial ventures: A vital tool towards success," presented at $10^{\text {th }}$ National Convention on Statistic (NCS) EDSA, 2 October, 2007.
[14] H. Morton, "Financial literacy: A primer for policy makers," presented at National Conference of State Legislatures, Denver, Colorado, 2005.

[15] Ray Morgan Research (RMR), ANZ Survey of Adult Financial Literacy in Australia: Final Report, Melbourne: Ray Morgan Research, May 2003.

[16] Hunter, Learning through Indigenous Business, National Centre for Vocational Education Research, South Australia, p. 72, 1999.

[17] P. S. Scherrer, "Management turnarounds: Diagnosing business ailments," Corporate Governance, vol. 3, no. 4, pp. 52-62, 2003.

[18] Berita Harian. (28 June, 2010). [Online]. Available: http://www.bharian.com.my/

[19] Berita Harian. (2 June, 2010). [Online]. Available: http://www.bharian.com.my/

[20] C. W. Hofer and R. Charan, "The transition to professional management: Mission impossible?” American J. of Small Business, vol. 9, no. 1, pp. 1-11, 1984.

[21] M. A. Abdullah, "Inter-firm linkages and the performance of urban small firms in Malaysia," Malaysian Management Review, vol. 30, no. 1, pp. 49-59, 1997.

[22] P. Kotler, Marketing Management, Analysis, Planning, Implementation and Control, USA: Prentice Hall, 2010.

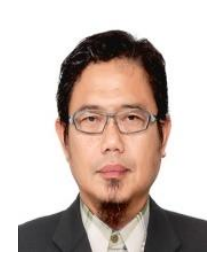

Abu Bakar Sedak has more than 25 years' experience in various proven capacities in strategic sales and marketing management of many well-known brands. He is also frequently served as a motivator, professional trainer and consultant with many established institutions. He holds a master of marketing degree from The University of Newcastle, Australia. He currently holds a post as a senior lecturer in Universiti Teknologi PETRONAS.

Abu Bakar held managerial positions in various companies. These positions include product manager, area sales manager and senior manager, national sales and marketing. His areas of specializations include entrepreneurship, strategic brand management, strategic sales \& marketing management, professional selling, and marketing strategy. He had presented more than 30 research and concept papers on entrepreneurship and marketing both in local and international conferences and also in international journals. 